\title{
Why Does The Tax Knowledge Give Negative Effect on the Level of Tax Payer Compliance?
}

\author{
Ika Rediyana*, Hadri Mulya
}

Universitas Mercu Buana, J1. Meruya Selatan No.1, RT.4/RW.1, Meruya Sel., Kec. Kembangan, Kota Jakarta Barat, Daerah Khusus Ibukota Jakarta 11650, Indonesia

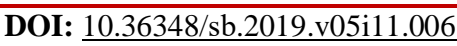

| Received: 08.11.2019 | Accepted: 14.11.2019| Published: 16.11.2019

*Corresponding author: Ika Rediyana

\section{Abstract}

This research is aimed to know why the tax knowledge gives negative effect to the level of tax compliance. The behavior of tax compliance may be seen by observing the understanding of the tax payers about the tax information which is manifested in the increase of tax payer compliances. The data collection is done by distributing questionnaire and the number of sample is 125 respondents. The result shows that the tax knowledge gives negative effect on the level of tax payer compliances. The significant level of the tax knowledge on the tax compliance is 0,927 dan $\beta-0,010$.

Keywords: Tax, Tax Knowledge, Tax Compliance.

Copyright @ 2019: This is an open-access article distributed under the terms of the Creative Commons Attribution license which permits unrestricted use, distribution, and reproduction in any medium for non-commercial use (NonCommercial, or CC-BY-NC) provided the original author and source are credited.

\section{INTRODUCTION}

The tax acceptance is one of the biggest income resources in Indonesia, and the function of tax is as budgeter [1]. In this case, Directorate General of Taxes (DJP) is appointed by the government to increase the Nation's income. To improve their services, Directorate General of Taxes (DJP) creates a new innovation in tax services. Self Assesment System is a tax collection system in Indonesia. The innovation created by Directorate General of Taxes (DJP) to improve the quality of services is by using e-SPT program. The tax report by e-SPT is designed to overcome the weakness of manual tax report that must attach the document (hardcopy) and the process of reporting takes a long time. The implementation of online taxation application is based on the Decree of
Directorate General No. Kep-88/PJ/2004 related with the submission of tax report through E-filling.

The tax reporting by online taxation application has improved significantly in the last few years. In the year of 2015 since this application was introduced to the community, the Directorate General of Taxes determined the target of 2 million users, while in 2016 it increased 28,57\% i.e. 7 Juta users. Meanwhile in 2017 the target of Directorate General of Taxes (Direktorat Jenderal Paja (DJP) increased 100\% i.e. 14 million users. In 2018 Directorate General of (DJP) published the regulation on Tax Return explaining that since 1 April 2018 all tax reports must use e-filling, but the users only increased $77,77 \%$ since 2017 . In 2019, Directorate General of Taxes (Direktorat Jenderal Pajak (DJP)) aims the increase of $75 \%$ users compared to last years.

Table-1: Destination Statement of Directorate General of Taxes (DJP) Tax Year 2015-2019

\begin{tabular}{|c|c|c|c|c|c|}
\hline Indikator & $\mathbf{2 0 1 5}$ & $\mathbf{2 0 1 6}$ & $\mathbf{2 0 1 7}$ & $\mathbf{2 0 1 8}$ & $\mathbf{2 0 1 9}$ \\
\hline Tax Ratio* & $13.2 \%$ & $14.2 \%$ & $14.6 \%$ & $15.2 \%$ & $16 \%$ \\
\hline Penerimaan Pajak & $1.294 \mathrm{~T}$ & $1.512 \mathrm{~T}$ & $1.737 \mathrm{~T}$ & $2.007 \mathrm{~T}$ & $2.329 \mathrm{~T}$ \\
\hline SPT melalui $e$-Filing & 2 Juta & 7 Juta & 14 Juta & 18 Juta & 24 Juta \\
\hline Jumlah WP terdftar & 32 Juta & 36 Juta & 40 Juta & 42 Juta & 44 Juta \\
\hline \multicolumn{7}{|c}{ *Terasuk 1\% pajak dearah } \\
\hline
\end{tabular}


Ika Rediyana \& Hadri Mulya., Sch Bull, Nov 2019; 5(11): 639-643

The realization of Tax Return (SPT) by using taxation application in 2015 was 2.804 .510 (130,23\%), $8.441 .188(120,58 \%)$ in 2016 and 17.196 .200 $(122,83 \%)$ in 2017 . In procentage, the submission of Tax Return by taxation application is increasing from year to year.

Table-2: Table of Realization of Tax Return Submission by Taxation Application

\begin{tabular}{|c|c|c|c|}
\hline Tahun & Target & Realisasi & Capaian \\
\hline 2015 & 2 Juta & 2.804 .510 & $130.23 \%$ \\
\hline 2016 & 7 Juta & 8.441 .188 & $120.58 \%$ \\
\hline 2017 & 14Juta & 17.196 .200 & $122.83 \%$ \\
\hline \multicolumn{4}{|c}{ Source: LAKIN DJP 2017 }
\end{tabular}

However, the level of tax compliance is still very low if compared with the number of tax payers. At least in 2016 there were 18 million tax payers but only around 10 millions tax payers who reported tax return. In 2017, only 9 million tax payers out of 18 millions who reported tax return, in other word, only $50 \%$ of tax payers who reported tax return.

The objective of this research is to see if the online taxation application, tax knowledge, examination and punishment influence the level of tax payer compliance registered in North Jakarta tax office.

\section{LITERATURE REVIEW}

The acceptance of the use of information technology is influenced by some perceptions, the research was firstly done by Davis [2]. The use of information system is influenced by some factors such as its easy access and benefits.

The application of online taxation system here is aimed to facilitate and answer the problem of tax payer in general. Planned Behavioral theory is the new version of Reason Action theory by fisbein and Ajzen [3].

The result of any things of human to understand something is named knowledge [4]. Based on Waluyo [5] tax may be concluded as some elements such as tax is an obligation that must be fulfilled by the community, being forced, and has to be paid to the Nation and punishment is the consequence if it is not fulfilled.

The condition in which the tax obligation may be fulfilled, where there is Risk Aversion Theory dan Tax Morale Theory, may be defined as compliance according to Erard dan Feinstein [6].

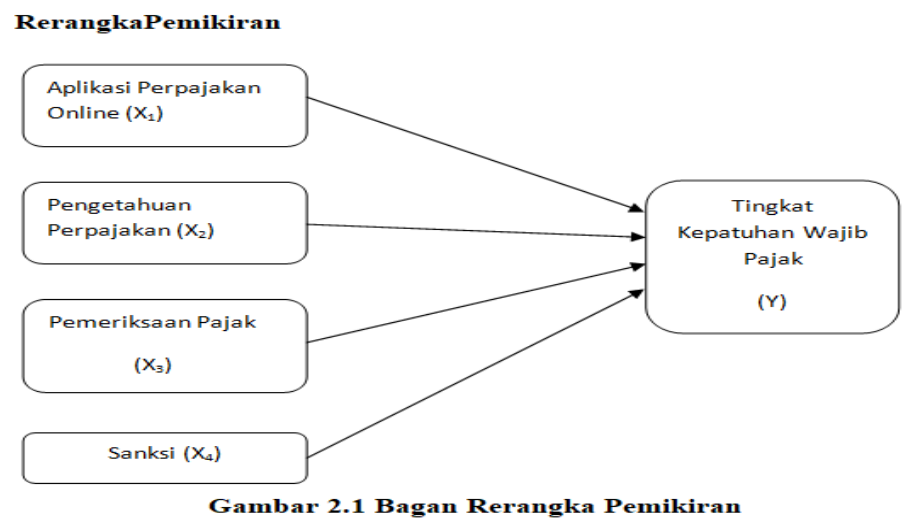

Research by Goerge Mihu [7] described that the tax authority will always use law and regulation as basic of examination and the examination will limit the business hour of the tax payer by implementation of tax audit program based on the agreement of tax payer and the approval of tax office so that it is expected that the examination will be effective and may improve the tax compliance.

Waluyo [8] emphasized that tax examination influences the National income and Tax Payer Compliance. Based on the result of research by Umar Danda \& Oyedokun [9], the tax audit has significant influence towards the tax compliance.
The online taxation application is a new innovation of Directorate General of Taxes (DJP) which is aimed to facilitate the tax reporting system that may increase the level of tax payer compliance Ragupathi, $\mathrm{M}$ [10].

The punishment given by Directorate General of Taxes (DJP) is aimed to anticipate the tax offence by tax payers. This statement is against the research by Oladipupo \& Obazee [11] explaining that the punishment has no effect towards the tax compliance. The former research by Waluyo also described that punishment influences the tax compliance [12]. 
Ika Rediyana \& Hadri Mulya., Sch Bull, Nov 2019; 5(11): 639-643

\section{RESEARCH METHOD}

This Research uses questionnaire fulfilled by the respondents. Primary data is collected during research period and then presented in table or diagram.

Population of this research is 1322. Purposive Sampling Method is used, sample determination is based on certain considerations namely year of tax payer, active tax payer and status of Tax Payer Identification Number (NPWP).

Data collection technique is done through survey and used instrument to measure a phenomenon. The researcher used questionnaire as assistive tool. The model that will be used by the researcher to test hypotheses is as follow:

Compliance $=\alpha+\beta_{1}$ APO $+\beta_{2}$ Know $+\beta_{2}$ Audit $+\beta_{2}$ Sanksi $+\varepsilon$

Note:

$\begin{array}{ll}\text { Compliace } & : \text { Level of tax compliance } \\ \alpha & \text { : constant } \\ \beta 1 \text { APO } & \text { : Online Taxation Application } \\ \beta_{2} \text { Know } & : \text { Tax Knowledge } \\ \beta_{2} \text { Audit } & : \text { Tax Examination } \\ \beta_{2} \text { Sanksi } & \text { : Punishment } \\ \varepsilon & : \text { Residual }\end{array}$

\section{RESULT AND DISCUSSION}

In North Jakarta Tax Office KPP Madya Jakarta Utara, there are 59 WP NE, 1 active tax payer non NPWP dan 1262 active tax payers. The object of this research is variable that is observed in a research. One of facilities provided by North Jakarta tax office is facilitating the tax payer who cannot use E billing application by providing services through Whatapps application in which the tax payer should only submit the NPWP code, thus automatically the tax officer will process the code through Whatsapp.

The result of descriptive statistic test shows that the value of online taxation application, Tax Knowledge, Tax Examination and Punishment is lower thatn the mean value and indicates that the distribution is normal and not bias. The regression equation model is as follow:

$Y=0,358+0,027 X_{1}-0,010 X_{2}+0,259 X_{3}+0,621 X_{4}$

The result of this research shows Asymp, Sig. (2-tailed) i.e. the significant value is 0.078 higher than level of significant 0,05 , showing that data of this research is distributed normally if we see from each independent variable. This research does not show multikolinearitas.

Output of coefficient determination test is presented in Table-3.

Table-3: Hasil Uji Koefisien Determinasi $\left(\mathbf{R}^{2}\right)$

\begin{tabular}{|c|c|c|c|c|}
\hline \multicolumn{5}{|c|}{ Model Summary } \\
\hline Model & $\mathbf{R}$ & R Square & AdjustedvR Square & Std. Error of the Estimate \\
\hline 1 & $.862^{\mathrm{a}}$ & .734 & .735 & .46059 \\
\hline \multicolumn{5}{|c|}{$\begin{array}{l}\text { a. Predicors: (Consult), Sanksi Pajak (X4), APO (X1), Knowledge (X2) } \\
\text { b. Dependent Variable: Compliance (Y) }\end{array}$} \\
\hline \multicolumn{5}{|c|}{ Sumber: Output SPSS 22} \\
\hline
\end{tabular}

$\mathrm{R}$ Square $\mathrm{h}$ value is 0.7341 which means that $73,4 \%$ dependent variables may be explained by independent variable while $26,6 \%$ of it explained by other variables that are not included in regression model of this research.

Table-4: Hasil Pengujian Simultan (Uji F)

\begin{tabular}{|c|c|c|c|c|c|c|}
\hline \multicolumn{7}{|c|}{ ANOVA* } \\
\hline \multicolumn{2}{|r|}{ Model } & Sum of Squares & df & Mean Square & $\mathbf{F}$ & Sig. \\
\hline \multirow{3}{*}{1} & Regression & 73.693 & 3 & 18.423 & 86.842 &, $000^{6}$ \\
\hline & Residual & 25.457 & 120 & .212 & & \\
\hline & Total & 99.150 & 124 & & & \\
\hline & b. Predico & $\begin{array}{c}\text { a. Depend } \\
\text { ult), Sanksi Paja }\end{array}$ & $\begin{array}{l}\text { ariab } \\
\text {, AP }\end{array}$ & $\begin{array}{l}\text { mpliance (Y) } \\
\text { 1), Knowledge }\end{array}$ & Pemeri & \\
\hline
\end{tabular}

F-test value is 0,000 , in which this significant value is lower than 0,05 or $5 \%$ so that simultaneously influence the dependent variables i.e. Level of Tax Payer Compliance. 
Ika Rediyana \& Hadri Mulya., Sch Bull, Nov 2019; 5(11): 639-643

Table-5: Hasil Pengujian Parameter Individual (Uji t)

\begin{tabular}{|c|c|c|c|c|c|c|}
\hline \multicolumn{7}{|c|}{ Coefficients $^{\mathbf{a}}$} \\
\hline \multicolumn{2}{|c|}{ Unstandardized Coefficients } & \multicolumn{3}{c|}{ Standardize d Coefficients } \\
\hline \multirow{4}{*}{ Model } & B & Std. Error & Beta & t & Sig. \\
\hline \multirow{4}{*}{1} & (Consult) &, 358 &, 194 & & 1,842 &, 068 \\
\cline { 2 - 7 } & APO (X1) &, 027 &, 091 &, 027 &, 298 &, 766 \\
\cline { 2 - 7 } & Knowledge (X2) &,- 010 &, 104 &,- 009 &,- 092 &, 927 \\
\cline { 2 - 7 } & Audit &, 259 &, 095 &, 268 & 2,731 &, 007 \\
\cline { 2 - 7 } & Sanksi Pajak (X4) &, 621 &, 061 &, 646 & 10,140 &, 000 \\
\hline \multicolumn{7}{|c|}{ a. Dependent Variable: Compliance (Y) } \\
\hline
\end{tabular}

APO does not show significant influence towards level of compliance ie. 0,027 with significant value of 0,068. Tax Knowledge has no significant value towards level of compliance i.e. -0,010 with significant value of 0,927. Tax Examination shows significant value towards level of Compliance i.e. 0,259 with significant value of 0,007 . Punishment shows significant value towards level of compliance i.e. 0,621 with signicant level of 0,000 .

\section{DISCUSSION}

Knowledge is very important to realize the increase of tax compliance. It becomes important in creating the compliance behavior because basically the tax payer will not comply if they have no understanding about tax regulation. By the tax knowledge, it is expected to help the tax payer to facilitate them in fulfilling the tax obligation, so that the level of compliance may increase. In other words, as the tax knowledge of tax payers increases, so the level of tax compliance will also increase.

This research shows contradicted result with reality and the trend that as the tax knowledge increases so tax payers tend to offence the tax regulation, or in other words, as the skill of an individual increases so it is easier for them to manipulate the data. In this case, the more people understand the tax knowledge, it may be assumed that they will be more easy in manipulating the tax. Based on statistic and significance test, tax knowedge shows negative influence towardsthe level of tax payer compliance.

Based on facts, an individual who has good tax knowledge tends to do tax offences. The tax that is basically self assessment is often misinterpreted by people who have very good tax knowledge.

It also occurs in works where an individual has a certain position for a long period tends to manipulate the report. Thus, there may be cooperation between tax payers and tax officials who really understand the tax regulation.

Therefore, there should be rotation of position regularly to avoid such things. Besides that, the tax training should be introduced to community since they enter the productive age, thus they may understand the importance of tax that is collected from the citizen and used by them through facilities built by the government.

\section{CONCLUSION, LIMITATION PRACTICAL CONTRIBUTION}

AND

Based on this research, it may be concluded that tax knowledge does not always influence level of tax compliance significantly. As an individual has more understanding about a knowledge, it will be easier for them to make manipulation and finally they do tax offences.

By the limited time and scope of this research, it is expected that other researchers may add other variables for the development of this reaserch.

\section{REFERENCES}

1. Mardiasmo. (2009). Perpajakan Edisi Revisi Yogyakarta: CV Andi.

2. Davis, F. D. (2000). Percevied Usefulness, Percevied Ease of Use, and User Acceptence of Information Technology. Dalam MIS Quartely, 13(3):318-340.

3. Ajzen, I. (1985). From Intention to Action: A Theory pf Planned Behavior". In Kuhl, J., Beckman, J. (Eds.), Action-Control: From Cognition to Behavior (hal. 11-39). Heidelberg: Springer. Diunduh dari http://people.umass.edu/aizen pada 15 Februari 2019

4. Utomo. (2011). Pengaruh Sikap Kesadaran Wajib Pajak, Dan Pengetahuan Perpajakan Terhadap Kepatuhan Wajib Pajak Dalam Membayar Pajak Bumi dan Bangunan Di Kecamatan Pamulang Kota Tangerang Selatan.

5. Waluyo, W. (2007). Perpajakan Indonesia Pembahasan Sesuai dengan Ketentuan Perundangundangan Perpajakan dan Aturan Pelaksanaan Perpajakan Terbaru. Jakarta: Salemba Empat

6. Andreoni, J., Erard, B., Feinstain, J. (1998). Tax Compliance. Jurnal of Economic Literature 36(2): 818-860

7. Mihu, G. (2011). The Tax Audit-Prosedural Aspects and Consequences. Economic Management, and Financial Market, 6(1), 934941. 
Ika Rediyana \& Hadri Mulya., Sch Bull, Nov 2019; 5(11): 639-643

8. Waluyo, W. (2016). The Effect of Addition of Taxpayers Number, Tax Audit, Tax Billing, and Taxpayers Compliance toward Tax Revenue. The Accounting Journal of Binaniaga, 1(1), 37-44.

9. Oyedokun, D. U. (2018). Impact AssesmentOf Tax Audit on Tax Compliace: A Case Study of Katsina State Board of Internal Revenue. $A E$ FUNAI Journal of Accounting Bussines and Finance, 3(1).

10. Ragupati, M., \& Prabu, G. (2015). An Emperical Study of a Warness of e-filling. International
Journal of Advance ScintificReseacrh \& Development, 2.

11. Obazee, O. (2016). Tax Knowladge, Penalties and Tax Compliance in Small Medium Scale Enterprice in Nigeria. www.scrip.org/journal/ib Scientific Research Publishing

12. Waluyo, W. (2018). The Influence Of Perception On Corruption, Fiskal Services And Tax Sanction To Tax Compliance With Self Assesment System As Intervening Variable. International Journal of Bussines and Management Invention, 6(10):72-79. 